\title{
THE LEARNING OF ANGKLUNG IN THE LEARNING CULTURE OFPRIMARY TEACHER EDUCATION STUDENTS IN INDONESIA
}

\author{
${ }^{1}$ J. JULIA, ${ }^{2}$ PRANA DWIJA ISWARA, ${ }^{3}$ TEDI SUPRIYADI \\ ${ }^{1,2,3}$ Faculty of Education UNIVERSITAS PENDIDIKAN INDONESIA, INDONESIA \\ Email: ${ }^{1}$ juli@upi.edu, ${ }^{2}$ iswara@upi.edu, ${ }^{3}$ tedisupriyadi@upi.edu
}

\begin{abstract}
Learning angklung ensemble in music major is common, but learning angklung in the environment of student in Primary Teacher Education major is uncommon. This research aims at analyzing the culture of learning angklung in students not majoring in Music, but inPrimary Teacher Education. The method used was qualitative method by giving some angklung materialsto be studied and performed. During the learning process, the students were observed, then after the show they were assigned to fill the survey to strengthen the findings about their learning culture in studying angklung. The results of the study indicated that students inPrimary Teacher Educationhad high motivation to learn angklung, but did not have sufficient knowledge in basic theory of music, and in practice they had a learning culture that tended to be less able to hold a commitment to learn in groups or work together to perfectlycomplete an angklung music composition.
\end{abstract}

Keywords - Learning Angklung, Learning Culture, College Students, Primary Teacher Education.

\section{INTRODUCTION}

Each student in a campus environment has a different learning culture depending on the field of study he or she takes. Students in Primary Teacher Education major in Indonesia are burdened with five main areas of study that must be mastered by them, namely Mathematics, Language, Natural Sciences, Social Sciences, and Arts. Multiple areas of study leads students to have a different learning culture than students who only study one subject area. The observation results showedatendency of learning culture in which the students were seen negligent in deepening a field of science. The authors as lecturers in art (music), soughtto delve deeper into this issue through music course, especially through angklung ensemble learning.

This issue needs to be studied because the learning culture can basically affect the success of students in mastering or deepening a field of science. Howeverthe students' learning culture is, the students are still required to master all the material given in various fields of study. Thus, in time they will teach in elementary school, they are expected todeliver the material well to the learners, because they themselves have mastered the learning material well. In fact, by knowing the learning culture of students, it can be used as a basis for developing models, approaches, methods, or teaching strategies for teachers, so that teachers can create a positive learning culture. This is in accordance with the consideration that a rich body of literature attests to the importance of a positive teacher learning culture to improved learning and successful change in schools [1-6].

There are several studies in this topic. However, studies that specifically examine the students' learning culture, especially inthe case oflearning environment of Primary Teacher Education students, have not been found by researchers. In general, studies on this topic focus much on the culture of teachers or leaders in teaching or in organization, such as research by Haiyan, Walker and Xiaowei [2] and Peterson and Deal [5]. There arealso studies that focus on the search for a relationship between cultural identity and learning, as doneby Altugan [7], and the development of culture in learning by making thinking visible, as done by Delvin and England []. Therefore, this researchaims at examining the learning culture of students in Primary Teacher Education major in learning angklung ensemble. Learning angklung requires strong cooperation, discipline in practice, and a strong commitment to follow every process of practice until the show. For students majoring in Music, this can be a common thing. However, for students not majoring in Music, researchers have assumed this is not an ordinary thing so the emergence of problems is possible in the learning process.

\section{METHOD}

\subsection{Subject}

The research was conducted tostudents of Primary Teacher Education majorin one of universitiesin West Java province, Indonesia. Research subject was one class of students consisting of 33 students. The subjects consisted of 12 (36.4\%) male and 21 (63.6\%) females. They were aged from the range of 20-22 years. Origin of the area was quite diverse. As many as $15(45.5 \%)$ students were from Sumedang, nine (27.3\%) students were from Bandung, two (6.1\%) students werefrom Majalengka, one (3\%) studentwasfrom Cirebon, two (6.1\%) students were from Garut, one (3\%) student was from Indramayu, one $(3 \%)$ studentwas from Subang, one $(3 \%)$ student wasfrom other regions in West Java, and one (3\%) student wasfrom outside West Java. Geographically, the various regions had differences. They represented coastal areas, rice fields, mountains, and fields. 


\subsection{Procedures}

The steps taken in this research were: 1) students were taught angklung playing technique and how to read notation for angklung; 2) students in one class were assigned to study five angklung works in four voices within three months; and 3) angklung learning result was staged in public. Fig.1. showsan example of angklung work that must be studied and staged by the students, entitled Trimakasihku.

\section{TRIMAKASIHKU}

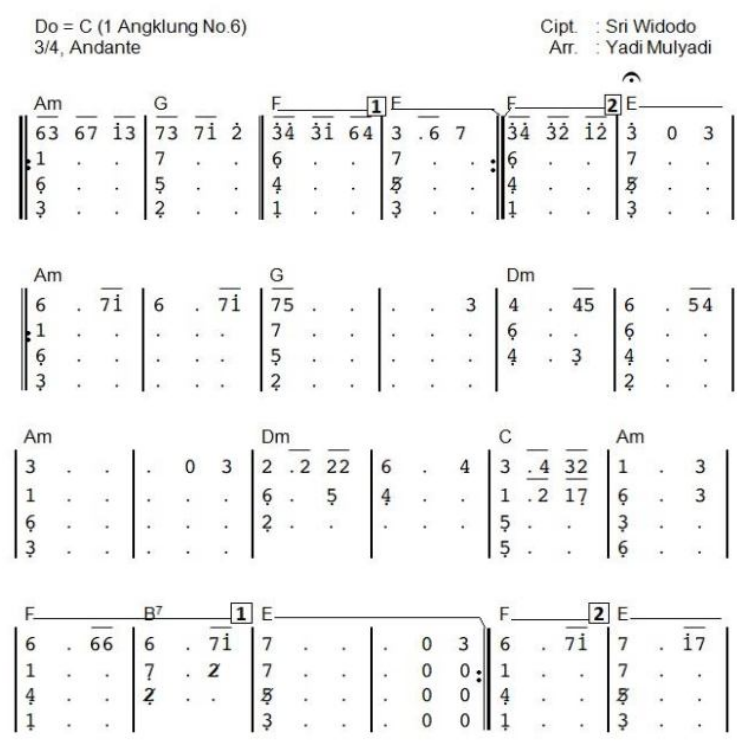

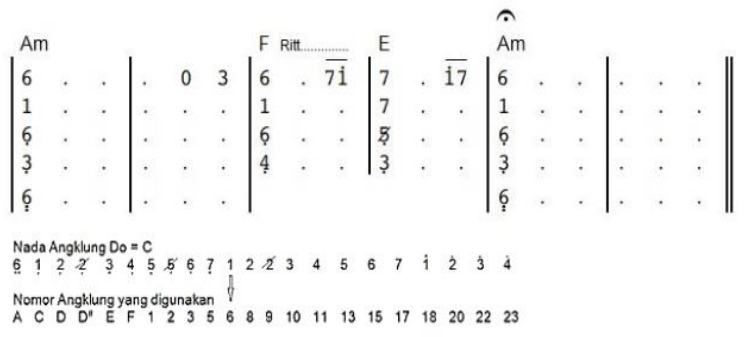

Fig.1.Angklung Scores of Trimakasihku Song

\subsection{Data Collection and Data Analysis}

Data collection was done in two stages. The first isby conducting observation during learning process and angklung show. The results of the show were recorded in order to get clear audio results for further analysis. The second is by administering surveyin the form of Likert scale, Guttman scale, and openendedquestionsto all students who were subjected to the study after the performance was completed. The results of data collection were then analyzed by descriptive analysis, quantitative calculation of survey results, and then interpreted and paired with relevant theories.

\section{RESULTS AND DISCUSSION}

\subsection{Experience in Learning Angklung}

Students were asked in advance about their experience in learning angklung. Their experience is illustrated in Table 1 below.

Table1: Students"' Experience in Learning Angklung

\begin{tabular}{lll}
\hline Experience in Learning Angklung & Yes & No \\
\hline Did you learn angklung in primary school? & 3 & 30 \\
Did you learn angklung in junior high school? & 4 & 29 \\
Did you learn angklung in senior high school? & 7 & 26 \\
Have you ever learnt angklung in an art studio? & 2 & 31 \\
Did you first learn angklung in college? & 22 & 11 \\
\hline
\end{tabular}

Based on Table 1, it could be identified that only a small number of students had ever learnt angklung in primary school or high school. According to the respondents, there were $11(33.3 \%)$ students who hadlearnt angklung before entering college, and the rest, as many as $22(66.7 \%)$ students, learnt angklung for the first time in college. Thus, most of the students had not experienced in playing angklung composition. Basically, it is very important to provide experience-based learning to learners, especially for practical lessons. The implications of adding experience as a central ingredient to the formula for explaining learning in schools are staggering[9].

\subsection{Motivation to Learn Angklung}

Having known the experience of students in learning angklung, researchers also dug data about their motivation to learn Angklung. Table 2 shows the students' motivation to learn angklung in Likert scale ( $\mathrm{SD}=$ Strongly Disagree; $\mathrm{D}=$ Disagree; FD = Fairly Disagree; $\mathrm{A}=$ Agree; $\mathrm{SA}=$ Strongly Agree) .

Table2: Students' Motivation to Learn Angklung

\begin{tabular}{llllll}
\hline Students' Motivation & SD & D & FD & A & SA \\
\hline $\begin{array}{l}\text { Being able to play angklung correctly is very } \\
\text { important. }\end{array}$ & 2 & 1 & 5 & 25 \\
$\begin{array}{l}\text { Learning to play angklung for the sake of } \\
\text { teaching in elementary school needs to be } \\
\text { done even in adulthood. }\end{array}$ & & 2 & 6 & 24 \\
$\begin{array}{l}\text { Only musicians or music teachers who need } \\
\text { to be able to play angklung properly. }\end{array}$ & 19 & 2 & 1 & 1 \\
\hline
\end{tabular}


Based on Table 2, it could be identified that the majority of students formedstrong opinions to demonstrate the magnitude of their motivation to learn and play angklung properly. In fact, they showed their disagreement if musicians or music teachers are the only ones who need to be able to play angklung properly. Thus, although the majority of them were not experienced in playing angklung, and were not students of music major, they showed a strong motivation to learn angklung. This was a positive thing, because "motivation increases the performance of learning"[10]. Motivation is a factor of high or low of the goal[10, 11$]$.

\subsection{Process and Results of Learning AngklungComposition}

The learning process of Angklung composition for three months was investigatedthrough survey and observation. Table 3 below shows some dataabout angklung learning process experienced by students.

Table3: Angklung Learning Process

\begin{tabular}{lll}
\hline Angklung Learning Process & Yes & No \\
\hline $\begin{array}{l}\text { Is learning angklung difficult? } \\
\begin{array}{l}\text { Does it need an extra hour outside the } \\
\text { lecture to master the angklung }\end{array}\end{array}$ & 33 & \\
$\begin{array}{l}\text { composition? } \\
\begin{array}{l}\text { Do you need help of friend/tutor to be } \\
\text { able to master angklung composition? }\end{array}\end{array}$ & 30 & 3 \\
$\begin{array}{l}\text { Are you one of the tutors who help } \\
\text { your friends to learn angklung? }\end{array}$ & 16 & 17 \\
\hline
\end{tabular}

Based on Table 3, it can be seen that as many as 13 $(39.4 \%)$ students admitted that studying angklung was not difficult, while the majority of students that were 20 students $(60.6 \%)$ admitted that learning angklung was difficult. In fact, all students recognized the need for additional hours outside the lecture to master the composition of angklung. They also recognized the need for help from friends to be able to master the composition of angklung. This showed that peer tutoring was an effective instructional strategy especially for students learning and developing new skills $[\underline{12}, \underline{13}]$, because basically, one of the ways of giving instruction is by making it more individualized, especially in large instrumental music classes, students can be used as tutors $[\underline{14}, \underline{15}]$. Through open-ended questions, the researcher askedfollow-up questionsto the students who found difficulties in studying the composition of angklung, "Why do you feel difficulty in studying the composition of angklung?" Some students or respondents $(\mathrm{R})$ answeredthe following reasons:

"Because playing angklung is not only limited to playing it, but every note on the song must be understood to be played." (R1)

"Many factors become obstacles in learning angklung that of course becomes a difficulty in learning angklung, one of them because it involves the group in forming a harmony, especially in angklung melody." (R2)

"Reading angklung notation is very difficult." (R3)

Meanwhile, some students who claimed no difficulty in studying the composition of angklung, gave the following reasons:

"If it continues to be done it will be easy and fun." (R4)

"The difficulty is only on people who are lazy. There is no such word as 'difficult' for those who are accustomed to. Instead, they will be addicted to playing angklung." (R5)

Through the reasons above, it could be identified that the problem in learning angklung lied in the weakness of students' ability in reading notation and creating harmony angklung in groups. This indicated students' lack of familiarityin reading notations and working in groups. Meanwhile, previous research results emphasized the importance of "relationships between music, mood, and cooperative behavior"[16].

Knowing the difference of the students' responses in studying angklung, the researcher asked, "To master angklung material, how many times do you practice in one week?" A total of $14(42.4 \%)$ students admitted to practice 1-3 times, 17 (51.5\% students admitted to practice 4-6 times, and two (6.1\%) students admitted to practicing more than 10 times. The amount of this exercise was far from the exercise portion of a professional musician, because to be a professional musician, it took 10,000 hours of practice in his life [17].

They were also asked about the results of angklung learning that they felt. Researchers offered five levels of ability in playing angklung composition with various indicators, namely beginner, elementary, intermediate, upper intermediate, and advanced. The survey results showed that three $(9.1 \%)$ students considered themselves in elementary level, 11 $(33.3 \%)$ students considered themselvesin intermediate level, 12 (36.4\%) students considered themselvesin upper intermediate level, and seven $(21.2 \%)$ students considered themselvesin the advanced level. Thus, the majority of students stated that they had better ability in playing angklung composition.

This was evidenced by researchers through observations in the performance. The results of angklung performance observation showed that students had good performance readiness seen from the aspects of performance and confidence, even from support of stage arrangement, sound system, and lighting. Meanwhile, from the aspect of angklung composition, there were weaknesses in some parts of angklung works, such as the presence of players who did not shakeangklung according to the arrangement, which could be caused by the lack of reckoning of angklung composition. There werealso playerswho werenot in accordance with the melody timing. This had been verified by the researchers through audio recording of the performance, which used Mixcraft 
Pro Studio 7application, PreSonus AudioBox USBrecording equipment, and Behringer C-2 condenser microphone to obtain a clear audio recording.

Through these findings, researchers conducted a search to clarify cases that occurred during the exercise process. Through an open-ended question, they were asked, "What obstacles did you face during the practice process for the angklung show?" Their answers can be seen as follows:

"There are friends who were difficult to manage, training time that was always late, members of the class who were absent from training, members who were not sensitive enough to beats, members who did not like to be given feedback, members who had slow memorizing skills, and more."(R6)

"The hurdle wasto unite the exercise schedule with other colleagues. In addition, most of the training schedulesstarted late due to many colleagues who arrived late during practice because in learning angklung when one member did not come it would interfere with the process of exercise and harmony while playing Angklung and would hamper the progress in practice. In addition, there were some signs in the melody/notation that had not been understood even after finding out for themselves, so we must wait for the lecturer to explain the meaning of the sign in the notation."(R7)

"The hurdle was sometimes it was difficult to memorize the songs but by practicingI was able to minimize it." (R8)

"I was afraid of playing wrong melodies." (R9)

"Unmanageable members." (R10)

Some of the reasons above explained the lack of knowledge in basic music theory, and learning culture in groups that were problematic especially in the issue of commitment to the group. In fact,it has beenaffirmed in several sources that cooperative behavior among teammates within a group tends to yield positive, synergistic outcomes when group interests are aligned with broader organizational goals [18-20].

Researchers also asked them about their readiness to teach angklung to students in elementary school. Researchers asked, "Do you dare to teach angklung to elementary school students?" As many as 17 (51.5\%) students expressed their courage, one (3\%) studentsaid they had no courage in doing so, and 15 (45.5\%) students answered hesitantly. Although more than 50\% students had expressed their courage, there are still many students who expressed doubt, so the strengthening of skills in playing the composition of angklung in groups is required.

\section{CONCLUSIONS}

From this research, it could be concluded that students of Primary School Education majorhad high motivation to learn angklung, but did not have sufficient knowledge in basic theory of music. In practice, they had a learning culture that tended to be less able to hold commitment to learn in groups or cooperate to finish an angklung musical composition in perfection.

\section{ACKNOWLEDGMENTS}

We would like to thank the Institute for Research and Community Service (Lembaga Pengabdian Pada Masyarakat, LPPM) of Universitas Pendidikan Indonesia that facilitated this research, and to DRPM of the Ministry of Research, Technology, and Higher Education who funded this research grant with the number 0045/E3/LL/2018.

\section{REFERENCES}

[1] A. Bryk, E. Camburn, and K. S. Louis, "Professional community in Chicago elementary schools: Facilitating factors and organizational consequences". Educational administration quarterly, Vol. 35,no, 5,pp. 751-781,1999.

[2] Q. Haiyan, A. Walker, and Y. Xiaowei, "Building and leading a learning culture among teachers: A case study of a Shanghai primary school". Educational Management Administration \& Leadership, Vol. 45,no, 1,pp. 101$122,2017$.

[3] R. Lindahl, "The role of organizational climate and culture in the school improvement process: A review of the knowledge base". Educational Leadership Review, Vol. 7,no, 1,pp. 19-29,2006.

[4] C. Schechter and M. Qadach, "Toward an organizational model of change in elementary schools: The contribution of organizational learning mechanisms". Educational Administration Quarterly, Vol. 48,no, 1,pp. 116-153,2012.

[5] K. D. Peterson and T. E. Deal, "How leaders influence the culture of schools". Educational leadership, Vol. 56,no,pp. 28-31,1998.

[6] H. E. Price, "Principal-teacher interactions: How affective relationships shape principal and teacher attitudes". Educational Administration Quarterly, Vol. 48,no, 1,pp. 39-85,2012.

[7] A. S. Altugan, "The relationship between cultural identity and learning". Procedia-Social and Behavioral Sciences, Vol. 186,no,pp. 1159-1162,2015.

[8] R. Delvin and S. England, "Developing a Culture of Learning by Making Thinking Visible". TEACH Journal of Christian Education, Vol. 10,no, 1,pp. 7,2016.

[9] R. E. Hansen, "The role and experience in learning: Giving meaning and authenticity to the learning process in schools". Journal of Technology Education, Vol. 11, no, 2,pp. 23-32,2000.

[10] R. Bakar, "The effect of learning motivation on student's productive competencies in vocational high school, West Sumatra". International Journal of Asian Social Science, Vol. 4,no, 6,pp. 722-732,2014.

[11] H. D. Brown and H. Lee, Teaching by principles: An interactive approach to language pedagogy. Vol. 1: Prentice Hall Regents Englewood Cliffs, NJ, 1994.

[12] P. Comfort and J. James McMahon, "The effect of peer tutoring on academic achievement". Journal of Applied Research in Higher Education, Vol. 6,no, 1,pp. 168175,2014 .

[13] P. Ward, et al., "Differential effects of peer-mediated accountability on task accomplishment in elementary physical education". Journal of Teaching in Physical Education, Vol. 17,no, 4,pp. 442-452,1998.

[14] L. Alexander and L. G. Dorow, "Peer tutoring effects on the music performance of tutors and tutees in beginning band classes". Journal of Research in Music Education, Vol. 31,no, 1,pp. 33-47,1983. 
The Learning of Angklung in The Learning Culture of Primary Teacher Education Students in Indonesia

[15] V. W. Harris and J. A. Sherman, "Effects of peer tutoring and consequences on the math performance of elementary classroom students". Journal of Applied Behavior Analysis, Vol. 6,no, 4,pp. 587-597,1973.

[16] K. M. Kniffin, et al., "The sound of cooperation: Musical influences on cooperative behavior". Journal of organizational behavior, Vol. 38,no, 3,pp. 372-390,2017.

[17] Djohan, Psikologi musik. Buku Baik, 2003.

[18] D. T. Campbell, "How individual and face-to-face group selection undermine firm selection in organizational evolution". Evolutionary dynamics of organizations, Vol. no,pp. 23-38,1994.

[19] A. M. Grant, Give and take: A revolutionary approach to success. New York: Penguin Books, 2013.

[20] K. M. Kniffin, "Evolutionary perspectives on salary dispersion within firms". Journal of Bioeconomics, Vol. 11, no, 1,pp. 23-42,2009. 